OPEN ACCESS

Edited by:

Peter lgaz,

Semmelweis University, Hungary

Reviewed by:

Matthias Kroiss,

University of Wuerzburg, Germany

Erika Hubina,

Hungarian Defense Forces Health

Center, Hungary

*Correspondence:

Mattia Barbot

mattiabarbot@alice.it

Specialty section:

This article was submitted to

Molecular and Structural

Endocrinology,

a section of the journal

Frontiers in Endocrinology

Received: 17 January 2019 Accepted: 02 May 2019 Published: 21 May 2019

Citation:

Barbot M, Ceccato F and Scaroni C

(2019) The Pathophysiology and Treatment of Hypertension in Patients With Cushing's Syndrome. Front. Endocrinol. 10:321. doi: 10.3389/fendo.2019.00321

\section{The Pathophysiology and Treatment of Hypertension in Patients With Cushing's Syndrome}

\author{
Mattia Barbot ${ }^{1 *}$, Filippo Ceccato $^{1,2}$ and Carla Scaroni ${ }^{1}$ \\ ${ }^{1}$ Endocrinology Unit, Department of Medicine DIMED, University of Padova, Padova, Italy, ${ }^{2}$ Department of Neurosciences \\ (DNS), University of Padova, Padova, Italy
}

When hypertension, a pathology that is frequently found in the general population, presents in a young patient, secondary causes such as Cushing's syndrome (CS), a rare disease characterized by long-term elevated cortisol levels, should be considered. Present in $\sim 80 \%$ of CS patients independently of their age and sex, hypertension is one of the pathology's most prevalent, alarming features. Its severity is principally associated with the duration and intensity of elevated cortisol levels. Prompt diagnosis and rapid initiation of treatment are important for reducing/delaying the consequences of hypercortisolism. Glucocorticoid excess leads to hypertension via a variety of mechanisms including mineralocorticoid mimetic activity, alterations in peripheral and renovascular resistance, and vascular remodeling. As hypertension in CS patients is caused by cortisol excess, treating the underlying pathology generally contributes to reducing blood pressure (BP) levels, although hypertension tends to persist in approximately $30 \%$ of cured patients. Surgical removal of the pituitary tumor remains the first-line treatment for both adrenocorticotropin hormone (ACTH) dependent and independent forms of the syndrome. In light of the fact that surgery is not always successful in curing the underlying disease, it is essential that other treatments be considered and prescribed as needed. This article discusses the mechanisms involved in the pathogenesis of CS and the pros and the cons of the various antihypertensive agents that are presently available to treat these patients.

\footnotetext{
Keywords: Cushing's syndrome, hypertension, glucocorticoids, glucocorticoid and mineralocorticoid receptors Cushing's disease, cortisol lowering medications, antihypertensive therapy
}

\section{INTRODUCTION}

Cushing's syndrome (CS) is a severe clinical condition caused by prolonged glucocorticoid excess (1). While exogenous corticosteroid therapy, which is applicable to $\sim 1 \%$ of the population, is quite common, endogenous hypercortisolism is a rare condition with an estimated incidence of 1.2-2.4 new cases/1.000.000/year (2). The syndrome is difficult to diagnose for a variety of reasons: its symptoms develop gradually, it is quite rare, and probably, most importantly, because it shares many features of a far more prevalent disorder, the metabolic syndrome. Both syndromes, are in fact characterized by abdominal obesity, glucose impairment, dyslipidemia, osteoporosis and arterial hypertension (3). Commonly featured in all forms of CS, hypertension represents the syndrome's second most common clinical finding after weight gain (4). 
Hypothetically, it is more prevalent in ectopic CS (ECS) given its severity (5), although one retrospective study reported that it was more common in adrenal cases with respect to pituitary-dependent ones (CD) (6). No gender-related differences in hypertension nor marked correlations with cortisol levels have been reported $(5,7,8)$. The majority of studies have shown that elevations in systolic and diastolic blood pressure (BP) values are of a similar entity in CS patients, and the loss of the typical physiological nocturnal fall, which represents an early hallmark, is almost certainly linked to a disruption in the cortisol circadian rhythm (9). Although a mild degree of overproduction of cortisol seems to have a limited impact on BP (10), prolonged excess appears to be linked to the development of hypertension due to vascular rearrangement and excessive fibrosis (11).

As pediatric CS patients tend to present hypertension even after remission, it would seem that children are prone to vascular remodeling during active disease stages, that leads to enduring hypertension even after the disease has been cured. Persistently high BP levels in these patients could also be due to the excessive glucocorticoid replacement therapy prescribed after remission $(12,13)$. The fact that young patients are at risk for residual hypertension and require long term monitoring to avoid post-surgery cardiovascular morbidity is well-established (14).

\section{MECHANISMS}

The pathophysiology of hypertension in CS is complex. The mineralocorticoid receptor (MR) seems to be activated following saturation of the $11 \beta$-hydroxysteroid dehydrogenase type 2 (HSD2) enzyme, which converts cortisol into cortisone, thus protecting it from cortisol binding (15) (Figure 1). Glucocorticoids, which are 100- to 1,000-fold higher with respect to aldosterone, can bind both to glucocorticoid and MR. In physiological conditions, $11 \beta-H S D 2$ converts cortisol to cortisone preventing it from binding to MR in target tissues, such as in the renal cortex, the colon, the salivary and sweat glands (16). Cortisol can, however, also bind to MR mimicking aldosterone action when its concentration exceeds the capacity of $11 \beta$-HSD2 to inactivate cortisol to cortisone resulting in higher sodium uptake and potassium excretion at the renal level. The blood volume expansion that follows suppresses endogenous renin secretion (17).

The molecular basis of mineralocorticoid-induced hypertension is linked to an overactivity of the epithelial $\mathrm{Na}+$ channel $(\mathrm{ENaC})$. It has been hypothesized that glucocorticoid receptor activation is responsible for enhanced $\mathrm{ENaC}$ and glomerular hyperfiltration, as neither selective mineralocorticoids nor glucocorticoid receptor antagonists appears to be able to fully revert cortisol's effects (18). These findings may explain why CS patients display more improvement when they are receiving mifepristone, a glucocorticoid receptor antagonist, than when they are taking MR antagonists $(19,20)$. A significant variability has also been noted as far as enzyme activity is concerned; some studies have suggested there is a positive correlation between $11 \beta$-HSD2 activity and Body Mass
Index (BMI), as overweight and obese patients may have an unsuppressed renin-angiotensin system (RAS) $(21,22)$.

\section{ACTIVATION OF THE RENIN-ANGIOTENSIN SYSTEM (RAS)}

Activation of the RAS via enhanced hepatic production of angiotensinogen has been described. Angiotensinogen, which is highly expressed in adipose tissues when other components of the RAS system are present, is able to generate angiotensin II and other vasoactive peptides. Low or suppressed renin levels are nevertheless quite usual in CS patients due to the negative feedback exerted by cortisol's mineralocorticoid activity, suggesting that there is a different activation mechanism (23). In fact, CS patients show a greater sensitivity to angiotensin II and its pressor activity at the peripheral levels. Glucocorticoids also enhance angiotensin II's action as a neurotransmitter leading to elevated sympathetic nerve activity, stimulating vasopressin release, and attenuating the arterial baroreceptor reflex (14).

\section{EFFECTS ON THE VASOREGOLATORY SYSTEMS AND VASCULATURE}

Endothelin-1 (ET-1), a potent vasoconstrictor peptide with mitogenic and atherogenic effects on the smooth muscular cells, plays an important role in BP control in cortisol-induced hypertension. In fact, while it has been found to be significantly elevated in CS patients, a decline has been noted following treatment (24). High plasma ET-1 levels probably promote early atherosclerosis and its progression in these patients (24), although no correlation has been found with disease severity. Persistently elevated ET-1 levels may depend in some cases on residual vascular damage (25). In addition, glucocorticoids inhibit nitric oxide synthase (NOS) expression, which is essential for adequate peripheral vasodilatation and may lead to higher BP levels (26). Glucocorticoids can also impair the production of other potent vasodilatators in the vascular endothelium such as prostacyclin, prostaglandins and kallikreins (15). Prolonged hypertension and glucocorticoid exposure lead to vasculature remodeling. In fact, angiogenic and growth factors including vascular endothelial growth factor (VEGF) and insulin lead to a higher media to lumen ratio, media thickness, and wall thickness that are responsible for enhanced small artery resistance (27).

\section{INCREASED SENSITIVITY TO CATECHOLAMINES}

Cortisol is needed for the survival and maintenance of chromaffin cells, permitting them to produce epinephrine through the conversion of norepinephrine operated by the phenylethanolamine $N$-methyltransferase enzyme whose transcription is glucocorticoid-dependent $(28,29)$. Glucocorticoids thus modulate the synthesis of neurotransmitters and the vascular response to catecholamines; they may also contribute to the detrimental effect of cortisol on blood vessels (18). 


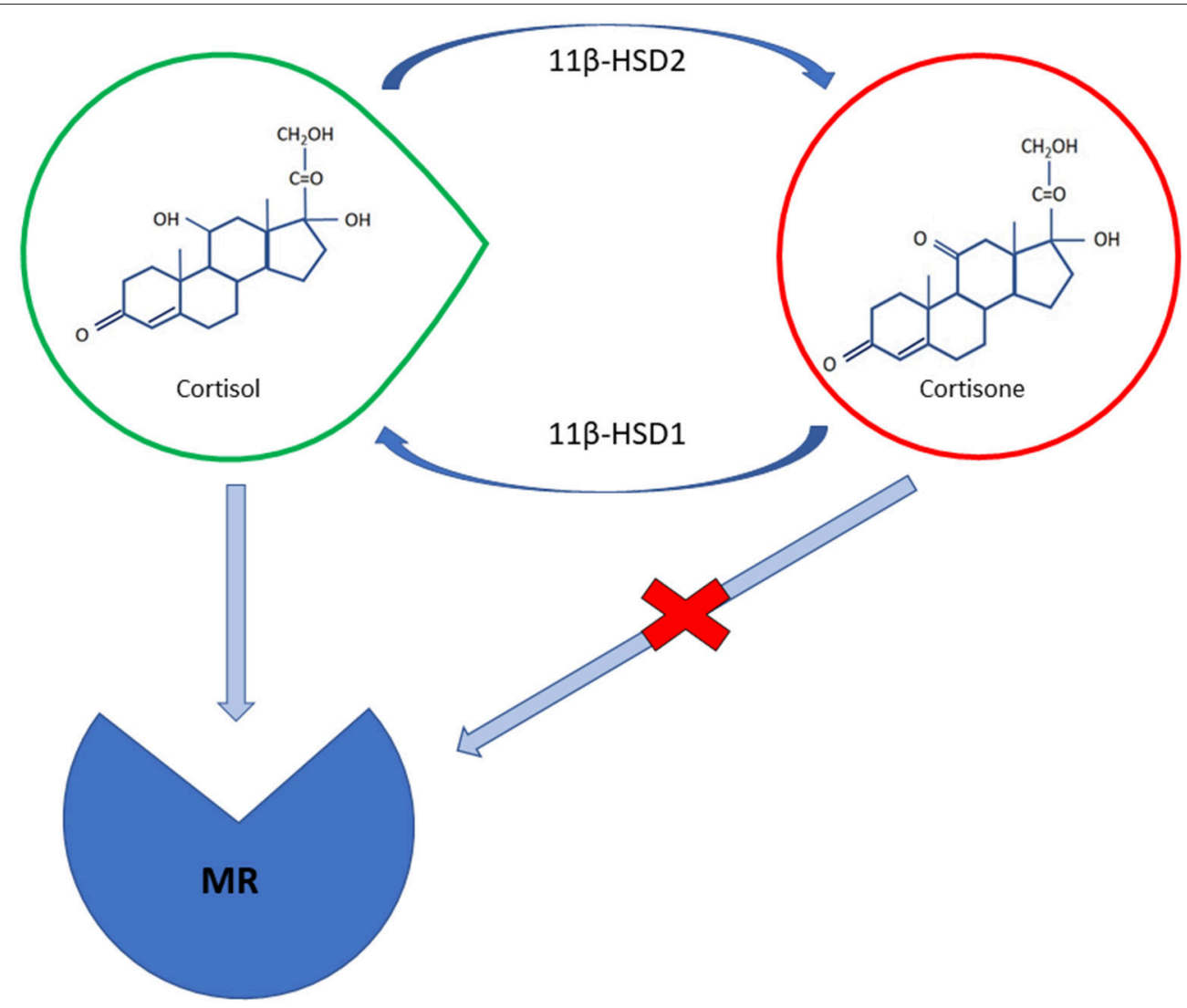

FIGURE 1 | A schematic illustration of cortisol and cortisone molecular structures; cortisol can bind to mineralocorticoid receptor (MR) with the same affinity as aldosterone; the $11 \beta-H S D 2$ enzyme converts cortisol in mineralocorticoid target tissues intos inactive cortisone preventing it from binding to MR. The intrinsic activity of $11 \beta-H S D 1$ in peripheral tissues, especially in the liver and in adipose cells, may constitute the main determinant as far as the control of BP and the metabolic manifestations of cortisol excess are concerned.

\section{METABOLIC CAUSES}

As explained above, CS has many features in common with the metabolic syndrome including dyslipidaemia, insulin resistance, and impaired glucose metabolism; all are linked to visceral adiposity and associated with hypertension. As these conditions may persist even after there has been a remission in CS, they presumably contribute to maintaining, at least to some extent, high BP and the risk of cardiovascular morbidity $(30,31)$. In fact, symptoms of the metabolic syndrome are often noted even after CS patients have been cured (32).

Visceral obesity may contribute to the development of obstructive sleep apnea syndrome (OSAS), which, surprisingly, has at times been described in lean CS patients (33), suggesting that cortisol has a direct effect on sleep impairment (34). OSAS can exacerbate hypertension in CS by increasing sympathetic tone during hypoxemic episodes; it is also associated with insulin resistance and diabetic autonomic neuropathy (33). Regular use of continuous positive airway pressure (CPAP) therapy has been found to markedly improve BP levels in patients with severe OSAS (35).

\section{CYTOKINES AND ADIPOKINES}

Visceral adiposity, which is typically present in CS and is associated with rises in pro-inflammatory cytokines such as TNF$\alpha$ and IL-6, may lead to the high rates of cardiovascular morbidity observed during active disease phases (36). As some features of the metabolic syndrome may persist even after remission, the impairment in cytokine and adipokine secretion might persist in cured CS patients, contributing to a proinflammatory state and to maintaining high BP levels via enhanced sodium retention $(37,38)$.

\section{ANTIHYPERTENSIVE TREATMENTS}

Since hypertension, which, as we have pointed out above, is quite prevalent in CS, is one of the major determinants of cardiovascular disease, it should be treated appropriately as soon as possible (1). While the underlying condition must in any case be addressed, it is important to remember that surgery is not always effective and that it may take a long time for cortisol-related comorbidities to normalize in cured patients (23). 
Antihypertensive treatment should be prescribed in accordance with updated guidelines both before and after surgery. Patients should also receive lifestyle education guiding them to improve their modifiable risk factors such as smoking and alcohol consumption (39). Other lifestyle changes such as losing weight and committing to an aerobic physical activity program may prove difficult to achieve in CS patients due to muscular myopathy, but they should, in any case, be encouraged $(4,40)$.

Almost all CS patients will require drug therapy which in most cases will involve a combination of antihypertensive agents in addition to lifestyle measures to achieve optimal BP control (23). Recently published guidelines on management of arterial hypertension have confirmed that diuretics, betablockers, calcium antagonists, ACE inhibitors, and sartans either as monotherapies or in combination can be used initially or at a later date to treat hypertension and to prevent cardiovascular events (39). In view of the impairment in RAS in CS, some have proposed using ACE inhibitors and sartans as the first line therapy in these cases because of their cardioprotective effects (25). It seems safe to say that since calcium antagonists have been found to be more effective than beta-blockers in delaying the progression of carotid atherosclerosis and in reducing left ventricular hypertrophy, proteinuria and stroke, they should be preferred to beta-blockers in the event add-on therapy is required (41).

The ACEinhibitor/calcium antagonist combination has proved to be more efficacious with respect to beta-blockers and diuretics in reducing cardiovascular events (42). Although beta-blockers may not represent the first-choice in CS due to their potentially unfavorable effects on glucose metabolism and heart rate, they should be taken into consideration for patients who have already experienced a myocardial infarction in which case vasodilating beta-blockers, such as labetalol, nebivolol, celiprolol, and carvedilol, should be preferred as they have fewer side effects with respect to non-selective beta-blockers $(43,44)$; they are also associated to a lower risk of new-onset diabetes and have fewer adverse effects on sexual function, which is often already impaired in male CS patients (4).

Should they be needed, hydrochlorothiazide diuretics can be used to manage cortisol-induced hypercalciuria to prevent calcium-containing kidney stone formation, a complication that is found in $\sim 50 \%$ of CS cases $(45,46)$. Thiazides should nevertheless be used carefully in order to avoid aggravating hypokalemia, hyperuricemia, gout or diabetes, all risks factors for CS $(47,48)$. Caution should be used if hydrochlorothiazide therapy is prolonged as it has recently been associated with an increased risk of melanoma (49). As diuretics can reduce serum potassium levels, they too should be used with caution (23).

Spironolactone, which has been found to have beneficial effects on heart failure patients, should be used to control hypokalemia if needed (50), and it can also be used as a thirdline drug to lower BP (39). As spironolactone may have antiandrogenic effects, it can be used in female patients, but it should be avoided in males since it has been associated to gynecomastia. Spironolactone metabolites such as canrenone should be preferred in male patients (51), and eplerenone can be prescribed as an alternative to spironolactone, especially in those males who have developed anti-androgen side effects (19). Although it is highly tolerated, eplerenone is not available in all countries and it is more expensive than amiloride and spironolactone (25). As no data are available on aliskiren, an expensive renin inhibitor which may cause complications in diabetics, it should be considered only when less expensive blockers of the RAS have untolerated side effects (25). Doxazosin was found to be effective by the Anglo-Scandinavian Cardiac Outcomes Trial (ASCOT) as a third-line therapy, although less efficacious than spironolactone in lowering BP in resistant hypertension (52). Although the drug has no specific contraindications in CS, it should be reserved as an add-on therapy or as a third-line option in cases of resistant hypertension after all other treatments have failed (39).

Using formulations combining more than one antihypertensive agents should be encouraged (39) as reducing the number of medications taken daily by CS patients who may need medication for numerous comorbidities (osteoporosis, diabetes, dyslipidaemia, psychiatric disorders) (4) can improve their short and in particular long-term adherence and increase BP control $(53,54)$. To summarize then, hypertension in CS should first be treated with ACEi or sartans at increasing doses. In the event they be unable to achieve satisfactory BP control, calcium antagonists and/or MR antagonists should be added, depending on the severity of the condition and the presence of hypokalemia (25). Acting practitioners must in any case take into consideration and evaluate both the possibility of drug interactions and any contraindications linked to hypercortisolemia (25).

\section{DISEASE REMISSION}

As it is the only therapy that can lead to a long-term remission and reduce mortality, surgery should be attempted whenever possible for all types of CS. Surgery aims to correct hypercortisolism without creating a permanent hormone deficiency (1). When feasible, it is the first line therapy, irrespective of the lesion's site (1). Selective transsphenoidal resection of ACTH-secreting pituitary adenoma is the treatment of choice (1). When disease remission is achieved, both systolic and diastolic BP tend to improve, but approximately one-third of all adult patients continue to have systolic and three-quarters diastolic hypertension (14). Only a weak correlation has been found between the severity of baseline BP values and postsurgery hypertension. The duration of preoperative hypertension seems nevertheless to be positively correlated with its persistence after surgery and probably reflects the impact of irreversible remodeling of the vasculature caused by long-term hypertension and/or a genetic predisposition (23).

\section{CORTISOL LOWERING MEDICATIONS}

Drugs specific for hypercortisolism are effective in controlling BP by reducing hormonal levels and thus preventing cortisone from binding to MR receptors (Table 1). Pasireotide, the somatostatin (SST) receptor ligand, which was the first pituitary-directed drug approved for CD treatment, can bind to four out of five SST 
TABLE 1 | Cortisol lowering medications, their effectiveness and effects on hypertension in CS patients.

\begin{tabular}{|c|c|c|c|c|c|c|}
\hline & Drug & Mechanism of action & Dose used & $\begin{array}{l}\text { Hormonal } \\
\text { control }\end{array}$ & Effects on BP & $\begin{array}{c}\text { Overall } \\
\text { effect on BP }\end{array}$ \\
\hline \multirow[t]{3}{*}{$\begin{array}{l}\text { Pituitary directed } \\
\text { drugs }\end{array}$} & Cabergoline & $\begin{array}{l}\text { Acts through D2R receptors } \\
\text { express on adenocorticotroph }\end{array}$ & 0.5-7 mg/week, oral & $25-40 \%$ & $\begin{array}{l}\downarrow \text { cortisol levels } \\
\uparrow \text { vasodilatation through D1 receptors }\end{array}$ & \\
\hline & Pasireotide & $\begin{array}{l}\text { Somatostatin multi-ligand with } \\
\text { particularly high SSTR5 }\end{array}$ & $\begin{array}{l}300-1,800 \mu \mathrm{g} / \text { day } \\
\text { Twice a day, sc }\end{array}$ & $20-62 \%$ & $\downarrow$ cortisol levels & \\
\hline & Retinoic Acid & $\begin{array}{l}\text { Reduces ACTH production } \\
\text { through inhibition of AP-I and } \\
\text { Nur77/Nurrl transcriptional } \\
\text { activities }\end{array}$ & $\begin{array}{l}\text { 10-80 mg/day } \\
\text { 1-3 times/day, oral }\end{array}$ & $20-50 \%$ & $\downarrow$ cortisol levels & \\
\hline \multirow[t]{4}{*}{$\begin{array}{l}\text { Steroidogenesis } \\
\text { inhibitors }\end{array}$} & Metyrapone & $11 \beta$-hydroxylase inhibitor & $\begin{array}{l}0.5-6 \mathrm{~g} / \text { day } \\
\text { 3-4 times/day, oral }\end{array}$ & $45-100 \%$ & $\begin{array}{l}\downarrow \text { cortisol levels } \\
\uparrow 11 \text {-deoxycorticosterone }\end{array}$ & ב \\
\hline & Ketoconazole & $\begin{array}{l}\text { Cholesterol side-chain cleavage } \\
\text { complex, } 17,20 \text {-lyase, } \\
11 \beta \text {-hydroxylase and } \\
17 \alpha \text {-hydroxylase inhibitor }\end{array}$ & $\begin{array}{l}\text { 200-1,200 mg/day } \\
\text { 2-3 times/day, oral }\end{array}$ & $\sim 50 \%$ & $\downarrow$ cortisol levels & \\
\hline & Osilodrostat & $\begin{array}{l}11 \beta \text {-hydroxylase and } \\
\text { aldosterone synthase inhibitor }\end{array}$ & $\begin{array}{l}\text { 4-60 mg/day } \\
2 \text { times/day, oral }\end{array}$ & $\sim 90 \%$ & $\begin{array}{l}\downarrow \text { cortisol levels } \\
\uparrow 11 \text {-deoxycorticosterone }\end{array}$ & \\
\hline & Mitotane & $\begin{array}{l}\text { Inhibition of steroid synthesis } \\
\text { (inhibition of SOAT1, intracellular } \\
\text { toxic lipid accumulation) }+ \\
\text { adrenolytic action }\end{array}$ & $\begin{array}{l}2-5 \mathrm{~g} / \text { day } \\
2-3 \text { times/day, oral }\end{array}$ & $\sim 70 \%$ & $\begin{array}{l}\downarrow \text { cortisol levels } \\
\downarrow \text { aldosterone levels }\end{array}$ & \\
\hline GR antagonist & Mifepristone & $\begin{array}{l}\text { Glucocorticoid receptor } \\
\text { antagonist }\end{array}$ & $\begin{array}{l}300-1,200 \mathrm{mg} / \text { day } \\
\text { Once daily, oral }\end{array}$ & NA & $\begin{array}{l}\downarrow \text { cortisol action on GR } \\
\uparrow \text { cortisol levels and its action on MR }\end{array}$ & \\
\hline
\end{tabular}

$\uparrow$ means increase; $\downarrow$ decrease; = neutral effect.

receptors and has a particular affinity for type 5 (SSTR5), the most prevalent in corticotroph tumors (55). Although pasireotide has been found to be effective in about $25 \%$ of patients by a 12-month phase III study (56), post-marketing data has shown that there was a higher rate of hormonal control in selected patients with mild CD (57-59). The drug was also found to be effective in reducing BP in CD; in fact, after a 6 month treatment period, both systolic and diastolic levels were reduced in all the treated patients, although the fall was more marked in those with controlled urinary free cortisol (UFC). The same pattern was noted at the 12 month mark, indicating an additional benefit independently of its effect on UFC secretion. Interestingly, pasireotide treatment lowered BP even in patients suffering from hypertension previously, regardless of the antihypertensive medication used (60). All the patients enrolled in a phase III trial receiving 10 or $30 \mathrm{mg}$ pasireotide monthly showed a mean $\mathrm{BP}$ reduction of 3-5 $\mathrm{mmHg}$ accompanied by weight and waist circumference improvements (61).

As diabetes mellitus is a frequent adverse event, which increases the risk of cardiovascular complications, in patients taking pasireotide, BP targets should probably be lowered in these patients (39). Cabergoline, a potent dopamine agonist, was found to normalize UFC in about $30 \%$ of CD patients and to reduce BP (62-64). The improvement in hypertension could be partially attributed to the drug's relaxing effect on the vascular smooth muscles causing lower peripheral resistance
(65). Originally developed as an antimycotic agent, ketoconazole has been widely used in CS because of its anti-steroidogenesis action causing inhibition of cytochrome P450 enzymes (66). Castinetti et al. reported a normalization in BP values and controlled (normalized) UFC in all the patients studied after 36 months of therapy with ketoconazole (67). The mean systodiastolic BP before ketoconazole treatment was begun, i.e., $148 / 105 \mathrm{mmHg}$, in patients receiving and continuing to receive anti-hypertensive treatment fell to $115 / 85 \mathrm{mmHg}$ (67). The drug's positive effects on $\mathrm{BP}$ were confirmed by a large retrospective multicentre study that reported that $40 \%$ of the patients studied showed an improvement in hypertension (68). Ketoconazole was also found to be superior to standard antihypertensive treatments suggesting that restoring normal cortisol levels is vital for achieving satisfactory BP control (69).

Metyrapone, another steroidogenesis inhibitor that acts by inhibiting 11-beta-hydroxylase activity, causes an increase in intermediates with mineralocorticoid activity leading to a potential worsening in hypertension and hypokalemia. These side effects are nevertheless counterbalanced by a reduction in UFC that has an overall neutralizing effect on BP (70-74). Osilodrostat, which acts on the same enzymes as metyrapone (11 $\beta$-hydroxylase and aldosterone synthase), has a stronger inhibitory effect (75). Despite its effectiveness in controlling hypercortisolism and $\mathrm{BP}$ in a proof of concept study in $\mathrm{CD}$ and hypertension in primary aldosteronism $(75,76)$, no 
significant improvement was observed at the end of a 22week phase II study (77). Combination therapy seemed at least as effective as each treatment prescribed separately (72, $78,79)$; the improvement in BP was more evident when both UFC and late night salivary cortisol were normalized. There was less clinical improvement when only one of the two parameters was normalized $(78,79)$. BP levels, which were studied in 62 patients treated preoperatively with ketoconazole and metyrapone alone or together, were found to be lower in the controlled group with respect to the partially controlled or uncontrolled groups (72). The Metyrapone-Ketoconazole combination also produced a significant fall in systolic and diastolic BP and made it possible to reduce the number of antihypertensive drugs required in patients with severe neoplastic hypercortisolism (80).

After in vitro studies demonstrated their antiproliferative and proapoptotic effects on corticotroph cells, peroxisome proliferator-activated receptor-agonists (PPAR $\gamma)$ such as rosiglitazone or pioglitazone were utilized in $\mathrm{CD}$ patients because of their positive impact on insulin resistance and their anti-inflammatory, anti-oxidative, and anti-proliferative effects on the cells of the vessel walls (81-83), but their effect on ACTH and cortisol reduction in humans was found to be unsatisfactory (84-86). As some sartans such as telmisartan, irbesartan, and losartan, also have peroxisome PPAR activity, their use should probably be preferred in CS $(23,87)$. Mitotane, an adrenolytic agent, which is rarely used in benign CS, was found to be effective and with long-lasting effects in controlling hypercortisolism by inhibiting steroidogenesis through the impairment of mitochondrial respiratory chain activity and in toxic lipid accumulation (88-90). The fact that the agent primarily reduces diastolic values can probably be explained by the fact that low doses destroy the zona fasciculata and reticularis, sparing somehow the zona glomerulosa and its mineralocorticoid secretion (91). Retinoic acid has also been shown to exert an antiproliferative action on corticotroph cells and has anti-secretory effects by reducing proopiomelanocortin (POMC) synthesis (92). The potential of retinoic acid and its 13cis-isomer (isotretinoin) was evaluated by two small pilot studies that examined 7 and $16 \mathrm{CD}$ patients treated with increasing drug doses for 12 months $(93,94) ; 3 / 7$ and $4 / 16$ patients, respectively,

\section{REFERENCES}

1. Nieman LK, Biller BMK, Findling JW, Murad MH, Newell-Price J, Savage MO, et al. Treatment of cushing's syndrome: an endocrine society clinical practice guideline. J Clin Endocrinol Metab. (2015) 100:2807-31. doi: 10.1210/jc.2015-1818

2. Clayton RN, Jones PW, Reulen RC, Stewart PM, Hassan-Smith ZK, Ntali G, et al. Mortality in patients with Cushing's disease more than 10 years after remission: a multicentre, multinational, retrospective cohort study. Lancet Diabetes Endocrinol. (2016) 4:569-76. doi: 10.1016/S2213-8587(16)30005-5

3. Debono M, Newell-Price JD. Cushing's syndrome: where and how to find it. Front Horm Res. (2016) 46:15-27. doi: 10.1159/000443861

4. Pivonello R, Isidori AM, De Martino MC, Newell-Price J, Biller BMK, Colao A. Complications of Cushing's syndrome: state of the art. Lancet Diabetes Endocrinol. (2016) 4:611-29. doi: 10.1016/S2213-8587(16)00086-3 were considered full responders. In addition, both studies reported an overall significant amelioration in systolic and diastolic BP during treatment $(93,94)$. Higher concentrations of the progesterone receptor antagonist mifepristone were able to block glucocorticoid receptors, with a binding affinity 3 times higher than that of dexamethasone without binding to the MR $(95,96)$. Out of the 40 hypertensive patients included in the SEISMIC study, $42.5 \%$ had a more than $5 \mathrm{mmHg}$ reduction with respect to baseline values in diastolic BP after 24 weeks of therapy, and it was possible to reduce the number of antihypertensive medications in $27.5 \%$ (97). Twelve patients had worse BP control; nine showed signs of MR activation linked to ACTH and cortisol increases which may not have been completely inactivated by HSD2 in the kidney, and thus binding to the MR (98).

\section{CONCLUSIONS}

A synergism of pathophysiological mechanisms causes the high rate of hypertension found in CS patients. The absence of nocturnal BP dipping profile is a typical feature of CS and reflects the impairment in circadian cortisol secretion. Above and beyond the hypertension that is specific to CS, a genetic predisposition could also play an important role in its development and persistence after CS remission. Controlling cortisol hypersecretion by surgical or farmacological means, such as cortisol lowering drugs or glucocorticoid receptor antagonists, can effectively lower the BP of most hypertensive CS patients and normalize it in $\sim 50 \%$ of cases. Patients not achieving remission or presenting residual hypertension may nevertheless require a long period of time before the effects of hypercortisolism dissipate. In the meantime, they must in any case continue to assume specific antihypertensive drugs. It is important to remember in view of the fact that hypertension is such a dangerous cardiovascular risk factor, CS patients should be diagnosed and treated promptly.

\section{AUTHOR CONTRIBUTIONS}

MB: literature revision and drafting of the article. FC: drafting of the article. CS: critical revision of the article and final approval.

5. Valassi E, Santos A, Yaneva M, Tóth M, Strasburger CJ, Chanson P, et al. The European Registry on Cushing's syndrome: 2-year experience. Baseline demographic and clinical characteristics. Eur J Endocrinol. (2011) 165:383-92. doi: 10.1530/EJE-11-0272

6. Hirsch D, Shimon I, Manisterski Y, Aviran-Barak N, Amitai O, Nadler V, et al. Cushing's syndrome: comparison between Cushing's disease and adrenal Cushing's. Endocrine. (2018) 62:712-20. doi: 10.1007/s12020-0 18-1709-y

7. Zilio M, Barbot M, Ceccato F, Camozzi V, Bilora F, Casonato A, et al. Diagnosis and complications of Cushing's disease: gender-related differences. Clin Endocrinol. (2014) 80:403-10. doi: 10.1111/cen.12299

8. Pecori Giraldi F, Moro M, Cavagnini F, Study Group on the HypothalamoPituitary-Adrenal Axis of the Italian Society of Endocrinology. Genderrelated differences in the presentation and course of Cushing's disease. J Clin Endocrinol Metab. (2003) 88:1554-8. doi: 10.1210/jc.2002-021518 
9. Pecori Giraldi F, Toja PM, De Martin M, Maronati A, Scacchi M, Omboni S, et al. Circadian blood pressure profile in patients with active Cushing's disease and after long-term cure. Horm Metab Res Horm Stoffwechselforschung Horm Metab. (2007) 39:908-14. doi: 10.1055/s-2007-992813

10. Guarnotta V, Amato MC, Pivonello R, Arnaldi G, Ciresi A, Trementino L, et al. The degree of urinary hypercortisolism is not correlated with the severity of cushing's syndrome. Endocrine. (2017) 55:564-72. doi: 10.1007/s12020-016-0914-9

11. Mancini T, Kola B, Mantero F, Boscaro M, Arnaldi G. High cardiovascular risk in patients with Cushing's syndrome according to 1999 WHO/ISH guidelines. Clin Endocrinol. (2004) 61:768-77. doi: 10.1111/j.1365-2265.2004.02168.x

12. Lodish MB, Sinaii N, Patronas N, Batista DL, Keil M, Samuel J, et al. Blood pressure in pediatric patients with Cushing syndrome. J Clin Endocrinol Metab. (2009) 94:2002-8. doi: 10.1210/jc.2008-2694

13. Güemes M, Murray PG, Brain CE, Spoudeas HA, Peters CJ, Hindmarsh $\mathrm{PC}$, et al. Management of Cushing syndrome in children and adolescents: experience of a single tertiary centre. Eur J Pediatr. (2016) 175:967-76. doi: 10.1007/s00431-016-2727-5

14. Magiakou MA, Smyrnaki P, Chrousos GP. Hypertension in Cushing's syndrome. Best Pract Res Clin Endocrinol Metab. (2006) 20:467-82. doi: 10.1016/j.beem.2006.07.006

15. Ferrari P, Krozowski Z. Role of the 11beta-hydroxysteroid dehydrogenase type 2 in blood pressure regulation. Kidney Int. (2000) 57:1374-81. doi: 10.1046/j.1523-1755.2000.00978.x

16. Quinkler M, Stewart PM. Hypertension and the cortisol-cortisone shuttle. $J$ Clin Endocrinol Metab. (2003) 88:2384-92. doi: 10.1210/jc.2003-030138

17. Baid S, Nieman LK. Glucocorticoid excess and hypertension. Curr Hypertens Rep. (2004) 6:493-9. doi: 10.1007/s11906-004-0046-0

18. Bailey MA, Mullins JJ, Kenyon CJ. Mineralocorticoid and glucocorticoid receptors stimulate epithelial sodium channel activity in a mouse model of Cushing syndrome. Hypertension. (2009) 54:890-6. doi: 10.1161/HYPERTENSIONAHA.109.134973

19. McMahon EG. Recent studies with eplerenone, a novel selective aldosterone receptor antagonist. Curr Opin Pharmacol. (2001) 1:190-6. doi: 10.1016/S1471-4892(01)00022-4

20. Nieman LK, Chrousos GP, Kellner C, Spitz IM, Nisula BC, Cutler $\mathrm{GB}$, et al. Successful treatment of Cushing's syndrome with the glucocorticoid antagonist RU 486. J Clin Endocrinol Metab. (1985) 61:536-40. doi: 10.1210/jcem-61-3-536

21. Müssig K, Remer T, Haupt A, Gallwitz B, Fritsche A, Häring H-U, et al. 11betahydroxysteroid dehydrogenase 2 activity is elevated in severe obesity and negatively associated with insulin sensitivity. Obes Silver Spring Md. (2008) 16:1256-60. doi: 10.1038/oby.2008.218

22. Salih M, Bovée DM, van der Lubbe N, Danser AHJ, Zietse R, Feelders $\mathrm{RA}$, et al. Increased urinary extracellular vesicle sodium transporters in Cushing syndrome with hypertension. J Clin Endocrinol Metab. (2018) 103:2583-91. doi: 10.1210/jc.2018-00065

23. Cicala MV, Mantero F. Hypertension in Cushing's syndrome: from pathogenesis to treatment. Neuroendocrinology. (2010) 92 (Suppl 1):44-9. doi: 10.1159/000314315

24. Kirilov G, Tomova A, Dakovska L, Kumanov P, Shinkov A, Alexandrov AS. Elevated plasma endothelin as an additional cardiovascular risk factor in patients with Cushing's syndrome. Eur J Endocrinol. (2003) 149:549-53. doi: 10.1530/eje.0.1490549

25. Isidori AM, Graziadio C, Paragliola RM, Cozzolino A, Ambrogio AG, Colao A, et al. The hypertension of Cushing's syndrome: controversies in the pathophysiology and focus on cardiovascular complications. J Hypertens. (2015) 33:44-60. doi: 10.1097/HJH.0000000000000415

26. Mangos GJ, Whitworth JA, Williamson PM, Kelly JJ. Glucocorticoids and the kidney. Nephrol Carlton Vic. (2003) 8:267-73. doi: 10.1111/j.1440-1797.2003.00215.x

27. Miljic P, Miljic D, Cain JW, Korbonits M, Popovic V. Pathogenesis of vascular complications in Cushing's syndrome. Horm Athens Greece. (2012) 11:21-30. doi: 10.1007/BF03401535

28. Zuckerman-Levin N, Tiosano D, Eisenhofer G, Bornstein S, Hochberg Z. The importance of adrenocortical glucocorticoids for adrenomedullary and physiological response to stress: a study in isolated glucocorticoid deficiency. J Clin Endocrinol Metab. (2001) 86:5920-4. doi: 10.1210/jcem.86.12.8106
29. Pirpiris M, Sudhir K, Yeung S, Jennings G, Whitworth JA. Pressor responsiveness in corticosteroid-induced hypertension in humans. Hypertension. (1992) 19 (6 Pt 1):567-74. doi: 10.1161/01.HYP.19.6.567

30. Schernthaner-Reiter MH, Siess C, Gessl A, Scheuba C, Wolfsberger S, Riss P, et al. Factors predicting long-term comorbidities in patients with Cushing's syndrome in remission. Endocrine. (2018) 56:GP203. doi: 10.1530/endoabs.56.GP203

31. Ferraù F, Korbonits M. Metabolic syndrome in Cushing's syndrome patients. Front Horm Res. (2018) 49:85-103. doi: 10.1159/000486002

32. Colao A, Pivonello R, Spiezia S, Faggiano A, Ferone D, Filippella M, et al. Persistence of increased cardiovascular risk in patients with Cushing's disease after five years of successful cure. J Clin Endocrinol Metab. (1999) 84:2664-72. doi: 10.1210/jcem.84.8.5896

33. Sacerdote A, Weiss K, Tran T, Rokeya Noor B, McFarlane SI. Hypertension in patients with Cushing's disease: pathophysiology, diagnosis, and management. Curr Hypertens Rep. (2005) 7:212-8. doi: 10.1007/s11906-005-0013-4

34. Venkatram S, Vakde T, Badipatla K, Niazi M, Diaz-Fuentes G. Unusual triad of obstructive sleep apnea, uncontrolled hypertension, and severe hypokalemia due to ectopic adrenocorticotropic secretion. J Bronchol Interv Pulmonol. (2014) 21:158-61. doi: 10.1097/LBR.0000000000000060

35. Parati G, Lombardi C, Hedner J, Bonsignore MR, Grote L, Tkacova R, et al. Position paper on the management of patients with obstructive sleep apnea and hypertension: joint recommendations by the European Society of Hypertension, by the European Respiratory Society and by the members of European Cost (cooperation in Scientific and Technological research) Action B26 on Obstructive Sleep Apnea. J Hypertens. (2012) 30:633-46. doi: 10.1097/HJH.0b013e328350e53b

36. Mirhafez SR, Mohebati M, Feiz Disfani M, Saberi Karimian M, Ebrahimi M, Avan A, et al. An imbalance in serum concentrations of inflammatory and anti-inflammatory cytokines in hypertension. J Am Soc Hypertens. (2014) 8:614-23. doi: 10.1016/j.jash.2014.05.007

37. Valassi E, Biller BMK, Klibanski A, Misra M. Adipokines and cardiovascular risk in Cushing's syndrome. Neuroendocrinology. (2012) 95:187-206. doi: 10.1159/000330416

38. Wen Y, Crowley SD. Renal effects of cytokines in hypertension. Curr Opin Nephrol Hypertens. (2018) 27:70-6. doi: 10.1097/MNH.0000000000000385

39. Williams B, Mancia G, Spiering W, Agabiti Rosei E, Azizi M, Burnier M, et al. 2018 ESC/ESH guidelines for the management of arterial hypertension: the task force for the management of arterial hypertension of the European Society of Cardiology and the European Society of Hypertension. J Hypertens. (2018) 36:1953-2041. doi: 10.1097/HJH.0000000000001940

40. Berr CM, Stieg MR, Deutschbein T, Quinkler M, Schmidmaier R, Osswald A, et al. Persistence of myopathy in Cushing's syndrome: evaluation of the German Cushing's Registry. Eur J Endocrinol. (2017) 176:737-46. doi: 10.1530/EJE-16-0689

41. Zanchetti A, Bond MG, Hennig M, Neiss A, Mancia G, Dal Palù $\mathrm{C}$, et al. Calcium antagonist lacidipine slows down progression of asymptomatic carotid atherosclerosis: principal results of the European Lacidipine Study on Atherosclerosis (ELSA), a randomized, double-blind, long-term trial. Circulation. (2002) 106:2422-7. doi: 10.1161/01.CIR.000003 9288.86470.DD

42. Dahlöf B, Sever PS, Poulter NR, Wedel H, Beevers DG, Caulfield M, et al. Prevention of cardiovascular events with an antihypertensive regimen of amlodipine adding perindopril as required versus atenolol adding bendroflumethiazide as required, in the Anglo-Scandinavian Cardiac Outcomes Trial-Blood Pressure Lowering Arm (ASCOT-BPLA): a multicentre randomised controlled trial. Lancet Lond Engl. (2005) 366:895-906. doi: 10.1016/S0140-6736(05)67185-1

43. Bakris GL, Fonseca V, Katholi RE, McGill JB, Messerli FH, Phillips RA, et al. Metabolic effects of carvedilol vs metoprolol in patients with type 2 diabetes mellitus and hypertension: a randomized controlled trial. JAMA. (2004) 292:2227-36. doi: 10.1001/jama.292.18.2227

44. Ayers K, Byrne LM, DeMatteo A, Brown NJ. Differential effects of nebivolol and metoprolol on insulin sensitivity and plasminogen activator inhibitor in the metabolic syndrome. Hypertension. (2012) 59:893-8. doi: 10.1161/HYPERTENSIONAHA.111.189589

45. Faggiano A, Pivonello R, Melis D, Filippella M, Di Somma C, Petretta $\mathrm{M}$, et al. Nephrolithiasis in Cushing's disease: prevalence, etiopathogenesis, 
and modification after disease cure. J Clin Endocrinol Metab. (2003) 88:2076-80. doi: 10.1210/jc.2002-021494

46. Coe FL, Worcester EM, Evan AP. Idiopathic hypercalciuria and formation of calcium renal stones. Nat Rev Nephrol. (2016) 12:519-33. doi: 10.1038/nrneph.2016.101

47. Greenberg A. Diuretic complications. Am J Med Sci. (2000) 319:10-24. doi: 10.1016/S0002-9629(15)40676-7

48. Mason JM, Dickinson HO, Nicolson DJ, Campbell F, Ford GA, Williams B. The diabetogenic potential of thiazide-type diuretic and betablocker combinations in patients with hypertension. J Hypertens. (2005) 23:1777-81. doi: 10.1097/01.hjh.0000177537.91527.09

49. Pottegård A, Pedersen SA, Schmidt SAJ, Hölmich LR, Friis S, Gaist D. Association of hydrochlorothiazide use and risk of malignant melanoma. JAMA Intern Med. (2018) 178:1120-2. doi: 10.1001/jamainternmed.2018.1652

50. Pitt B, Zannad F, Remme WJ, Cody R, Castaigne A, Perez A, et al. The effect of spironolactone on morbidity and mortality in patients with severe heart failure. Randomized aldactone evaluation study investigators. $N$ Engl J Med. (1999) 341:709-17. doi: 10.1056/NEJM199909023411001

51. Funder JW, Carey RM, Mantero F, Murad MH, Reincke M, Shibata H, et al. The management of primary aldosteronism: case detection, diagnosis, and treatment: an Endocrine Society Clinical Practice Guideline. J Clin Endocrinol Metab. (2016) 101:1889-916. doi: 10.1210/jc.2015-4061

52. Chapman N, Chang CL, Dahlöf B, Sever PS, Wedel H, Poulter NR, et al. Effect of doxazosin gastrointestinal therapeutic system as thirdline antihypertensive therapy on blood pressure and lipids in the Anglo-Scandinavian Cardiac Outcomes Trial. Circulation. (2008) 118:42-8. doi: 10.1161/CIRCULATIONAHA.107.737957

53. Corrao G, Parodi A, Zambon A, Heiman F, Filippi A, Cricelli C, et al. Reduced discontinuation of antihypertensive treatment by two-drug combination as first step. Evidence from daily life practice. J Hypertens. (2010) 28:1584-90. doi: 10.1097/HJH.0b013e328339f9fa

54. Gupta AK, Arshad S, Poulter NR. Compliance, safety, and effectiveness of fixed-dose combinations of antihypertensive agents: a meta-analysis. Hypertension. (2010) 55:399-407. doi: 10.1161/HYPERTENSIONAHA.109.139816

55. Arnaldi G, Boscaro M. Pasireotide for the treatment of Cushing's disease. Expert Opin Investig Drugs. (2010) 19:889-98. doi: 10.1517/13543784.2010.495943

56. Colao A, Petersenn S, Newell-Price J, Findling JW, Gu F, Maldonado M, et al. A 12-month phase 3 study of pasireotide in Cushing's disease. $N$ Engl J Med. (2012) 366:914-24. doi: 10.1056/NEJMoa1105743

57. Trementino L, Cardinaletti M, Concettoni C, Marcelli G, Polenta B, Spinello M, et al. Salivary cortisol is a useful tool to assess the early response to pasireotide in patients with Cushing's disease. Pituitary. (2015) 18:60-7. doi: 10.1007/s11102-014-0557-x

58. Trementino L, Zilio M, Marcelli G, Michetti G, Barbot M, Ceccato F, et al. The role of an acute pasireotide suppression test in predicting response to treatment in patients with Cushing's disease: findings from a pilot study. Endocrine. (2015) 50:154-61. doi: 10.1007/s12020-014-0499-0

59. Barbot M, Guarnotta V, Zilio M, Ceccato F, Ciresi A, Daniele A, et al. Effects of pasireotide treatment on coagulative profile: a prospective study in patients with Cushing's disease. Endocrine. (2018) 62:207-14. doi: 10.1007/s12020-018-1669-2.

60. Pivonello R, Petersenn S, Newell-Price J, Findling JW, Gu F, Maldonado M, et al. Pasireotide treatment significantly improves clinical signs and symptoms in patients with Cushing's disease: results from a Phase III study. Clin Endocrinol. (2014) 81:408-17. doi: 10.1111/cen.12431

61. Lacroix A, Gu F, Gallardo W, Pivonello R, Yu Y, Witek P, et al. Efficacy and safety of once-monthly pasireotide in Cushing's disease: a 12 month clinical trial. Lancet Diabetes Endocrinol. (2018) 6:17-26. doi: 10.1016/S2213-8587(17)30326-1

62. Pivonello R, De Martino MC, Cappabianca P, De Leo M, Faggiano A, Lombardi G, et al. The medical treatment of Cushing's disease: effectiveness of chronic treatment with the dopamine agonist cabergoline in patients unsuccessfully treated by surgery. J Clin Endocrinol Metab. (2009) 94:223-30. doi: 10.1210/jc.2008-1533
63. Godbout A, Manavela M, Danilowicz K, Beauregard H, Bruno OD, Lacroix A. Cabergoline monotherapy in the long-term treatment of Cushing's disease. Eur J Endocrinol. (2010) 163:709-16. doi: 10.1530/EJE-10-0382

64. Ferriere A, Cortet C, Chanson P, Delemer B, Caron P, Chabre O, et al. Cabergoline for Cushing's disease: a large retrospective multicenter study. Eur J Endocrinol. (2017) 176:305-14. doi: 10.1530/EJE-16-0662

65. Murphy MB. Dopamine: a role in the pathogenesis and treatment of hypertension. J Hum Hypertens. (2000) 14 (Suppl 1):S47-50. doi: 10.1038/sj.jhh.1000987

66. Feelders RA, Newell-Price J, Pivonello R, Nieman LK, Hofland LJ, Lacroix A. Advances in the medical treatment of Cushing's syndrome. Lancet Diabetes Endocrinol. (2018) 7:300-12. doi: 10.1016/S2213-8587(18)30155-4

67. Castinetti F, Morange I, Jaquet P, Conte-Devolx B, Brue T. Ketoconazole revisited: a preoperative or postoperative treatment in Cushing's disease. Eur J Endocrinol. (2008) 158:91-9. doi: 10.1530/EJE-07-0514

68. Castinetti F, Guignat L, Giraud P, Muller M, Kamenicky P, Drui D, et al. Ketoconazole in Cushing's disease: is it worth a try? J Clin Endocrinol Metab. (2014) 99:1623-30. doi: 10.1210/jc.2013-3628

69. Fallo F, Paoletta A, Tona F, Boscaro M, Sonino N. Response of hypertension to conventional antihypertensive treatment and/or steroidogenesis inhibitors in Cushing's syndrome. J Intern Med. (1993) 234:595-8. doi: 10.1111/j.1365-2796.1993.tb01018.x

70. Jeffcoate WJ, Rees LH, Tomlin S, Jones AE, Edwards CR, Besser GM. Metyrapone in long-term management of Cushing's disease. Br Med J. (1977) 2:215-7. doi: 10.1136/bmj.2.6081.215

71. Verhelst JA, Trainer PJ, Howlett TA, Perry L, Rees LH, Grossman AB, et al. Short and long-term responses to metyrapone in the medical management of 91 patients with Cushing's syndrome. Clin Endocrinol. (1991) 35:169-78. doi: 10.1111/j.1365-2265.1991.tb03517.x

72. Valassi E, Crespo I, Gich I, Rodríguez J, Webb SM. A reappraisal of the medical therapy with steroidogenesis inhibitors in Cushing's syndrome. Clin Endocrinol. (2012) 77:735-42. doi: 10.1111/j.1365-2265.2012.04424.x

73. Ceccato F, Zilio M, Barbot M, Albiger N, Antonelli G, Plebani M, et al. Metyrapone treatment in Cushing's syndrome: a real-life study. Endocrine. (2018) 62:701-11. doi: 10.1007/s12020-018-1675-4

74. Puglisi S, Perotti P, Barbot M, Cosio P, Scaroni C, Stigliano A, et al. Preoperative treatment with metyrapone in patients with cushing's syndrome due to adrenal adenoma. Endocr Connect. (2018) 56:P14. doi: 10.1530/endoabs.56.P14

75. Bertagna X, Pivonello R, Fleseriu M, Zhang Y, Robinson P, Taylor A, et al. LCI699, a potent $11 \beta$-hydroxylase inhibitor, normalizes urinary cortisol in patients with Cushing's disease: results from a multicenter, proof-of-concept study. J Clin Endocrinol Metab. (2014) 99:1375-83. doi: 10.1210/jc.2013-2117

76. Amar L, Azizi M, Menard J, Peyrard S, Watson C, Plouin P-F. Aldosterone synthase inhibition with LCI699: a proof-of-concept study in patients with primary aldosteronism. Hypertension. (2010) 56:831-8. doi: 10.1161/HYPERTENSIONAHA.110.157271

77. Fleseriu M, Pivonello R, Young J, Hamrahian AH, Molitch ME, Shimizu C, et al. Osilodrostat, a potent oral 11ß-hydroxylase inhibitor: 22week, prospective, Phase II study in Cushing's disease. Pituitary. (2016) 19:138-48. doi: 10.1007/s11102-015-0692-z

78. van der Pas R, van Esch JHM, de Bruin C, Danser AHJ, Pereira AM, Zelissen PM, et al. Cushing's disease and hypertension: in vivo and in vitro study of the role of the renin-angiotensin-aldosterone system and effects of medical therapy. Eur J Endocrinol. (2014) 170:181-91. doi: 10.1530/EJE13-0477

79. Barbot M, Albiger N, Ceccato F, Zilio M, Frigo AC, Denaro L, et al. Combination therapy for Cushing's disease: effectiveness of two schedules of treatment: should we start with cabergoline or ketoconazole? Pituitary. (2014) 17:109-17. doi: 10.1007/s11102-013-0475-3

80. Corcuff J-B, Young J, Masquefa-Giraud P, Chanson P, Baudin E, Tabarin A. Rapid control of severe neoplastic hypercortisolism with metyrapone and ketoconazole. Eur J Endocrinol. (2015) 172:473-81. doi: 10.1530/EJE-14-0913

81. Heaney AP, Fernando M, Yong WH, Melmed S. Functional PPAR-gamma receptor is a novel therapeutic target for ACTH-secreting pituitary adenomas. Nat Med. (2002) 8:1281-7. doi: 10.1038/nm784 
82. Heaney AP, Fernando M, Melmed S. PPAR-gamma receptor ligands: novel therapy for pituitary adenomas. J Clin Invest. (2003) 111:1381-8. doi: 10.1172/JCI200316575

83. Patel J, Anderson RJ, Rappaport EB. Rosiglitazone monotherapy improves glycaemic control in patients with type 2 diabetes: a twelve-week, randomized, placebo-controlled study. Diabetes Obes Metab. (1999) 1:165-72. doi: 10.1046/j.1463-1326.1999.00020.x

84. Ambrosi B, Dall'Asta C, Cannavo S, Libe R, Vigo T, Epaminonda $\mathrm{P}$, et al. Effects of chronic administration of PPAR-gamma ligand rosiglitazone in Cushing's disease. Eur J Endocrinol. (2004) 151:173-8. doi: 10.1530/eje.0.1510173

85. Cannavò S, Arosio M, Almoto B, Dall'Asta C, Ambrosi B. Effectiveness of long-term rosiglitazone administration in patients with Cushing's disease. Clin Endocrinol. (2005) 63:118-9. doi: 10.1111/j.1365-2265.2005.02285.x

86. Pecori Giraldi F, Scaroni C, Arvat E, Martin M, Giordano R, Albiger $\mathrm{N}$, et al. Effect of protracted treatment with rosiglitazone, a PPARgamma agonist, in patients with Cushing's disease. Clin Endocrinol. (2006) 64:219-24. doi: 10.1111/j.1365-2265.2006.02452.x

87. Rossi GP. Losartan metabolite EXP3179: an AT1-receptor-independent treatment strategy for patients with the metabolic syndrome? Hypertension. (2009) 54:710-2. doi: 10.1161/HYPERTENSIONAHA.109.138883

88. Baudry C, Coste J, Bou Khalil R, Silvera S, Guignat L, Guibourdenche J, et al. Efficiency and tolerance of mitotane in Cushing's disease in 76 patients from a single center. Eur J Endocrinol. (2012) 167:473-81. doi: 10.1530/EJE-12-0358

89. Hescot S, Slama A, Lombès A, Paci A, Remy H, Leboulleux S, et al. Mitotane alters mitochondrial respiratory chain activity by inducing cytochrome $c$ oxidase defect in human adrenocortical cells. Endocr Relat Cancer. (2013) 20:371-81. doi: 10.1530/ERC-12-0368

90. Sbiera S, Leich E, Liebisch G, Sbiera I, Schirbel A, Wiemer L, et al. Mitotane inhibits Sterol-O-Acyl transferase 1 triggering lipid-mediated endoplasmic reticulum stress and apoptosis in adrenocortical carcinoma cells. Endocrinology. (2015) 156:3895-908. doi: 10.1210/en.2015-1367

91. Daffara F, De Francia S, Reimondo G, Zaggia B, Aroasio E, Porpiglia $\mathrm{F}$, et al. Prospective evaluation of mitotane toxicity in adrenocortical cancer patients treated adjuvantly. Endocr Relat Cancer. (2008) 15:1043-53. doi: 10.1677/ERC-08-0103
92. Páez-Pereda M, Kovalovsky D, Hopfner U, Theodoropoulou M, Pagotto U, Uhl E, et al. Retinoic acid prevents experimental Cushing syndrome. J Clin Invest. (2001) 108:1123-31. doi: 10.1172/JCI11098

93. Pecori Giraldi F, Ambrogio AG, Andrioli M, Sanguin F, Karamouzis I, Karamouzis I, et al. Potential role for retinoic acid in patients with Cushing's disease. J Clin Endocrinol Metab. (2012) 97:3577-83. doi: 10.1210/jc.2012-2328

94. Vilar L, Albuquerque JL, Lyra R, Trovão Diniz E, Rangel Filho F, Gadelha $\mathrm{P}$, et al. The role of isotretinoin therapy for cushing's disease: results of a prospective study. Int J Endocrinol. (2016) 2016:8173182. doi: 10.1155/2016/8173182

95. Bourgeois S, Pfahl M, Baulieu EE. DNA binding properties of glucocorticosteroid receptors bound to the steroid antagonist RU-486. EMBO J. (1984) 3:751-5. doi: 10.1002/j.1460-2075.1984.tb01879.x

96. Castinetti F, Conte-Devolx B, Brue T. Medical treatment of Cushing's syndrome: glucocorticoid receptor antagonists and mifepristone. Neuroendocrinology. (2010) 92 (Suppl 1):125-30. doi: 10.1159/000314224

97. Fleseriu M, Biller BMK, Findling JW, Molitch ME, Schteingart DE, Gross $\mathrm{C}$, et al. Mifepristone, a glucocorticoid receptor antagonist, produces clinical and metabolic benefits in patients with Cushing's syndrome. J Clin Endocrinol Metab. (2012) 97:2039-49. doi: 10.1210/jc.2011-3350

98. van Uum SHM, Lenders JWM, Hermus ARMM. Cortisol, 11betahydroxysteroid dehydrogenases, and hypertension. Semin Vasc Med. (2004) 4:121-8. doi: 10.1055/s-2004-835369

Conflict of Interest Statement: The authors declare that the research was conducted in the absence of any commercial or financial relationships that could be construed as a potential conflict of interest.

Copyright (c) 2019 Barbot, Ceccato and Scaroni. This is an open-access article distributed under the terms of the Creative Commons Attribution License (CC BY). The use, distribution or reproduction in other forums is permitted, provided the original author(s) and the copyright owner(s) are credited and that the original publication in this journal is cited, in accordance with accepted academic practice. No use, distribution or reproduction is permitted which does not comply with these terms. 